medRxiv preprint doi: https://doi.org/10.1101/2020.01.13.20017335; this version posted January 16, 2020. The copyright holder for this preprint (which was not certified by peer review) is the author/funder, who has granted medRxiv a license to display the preprint in

All rights reserved. No reuse allowed without permission.

\title{
tDCS to the left DLPFC improves cognitive control but not action cancellation in patients with ADHD: a behavioral and electrophysiological study
}

Laura Dubreuil-Vall, MSc ${ }^{1,2,3,+}$, Federico Gomez-Bernal, MD ${ }^{1}$, Ana C. Villegas, $\mathrm{MD}^{1}$, Patricia Cirillo, $\mathrm{PhD}^{1}$, Craig Surman, $\mathrm{PhD}^{1}$, Giulio Ruffini, $\mathrm{PhD}^{3}$, Alik S. Widge, $\mathrm{PhD}^{1,4}$, Joan A. Camprodon, $\mathrm{PhD}^{1}$

${ }^{I}$ Department of Psychiatry, Massachusetts General Hospital, Harvard Medical School.

${ }^{2}$ Department of Psychiatry and Clinical Psychobiology, Universitat de Barcelona.

${ }^{3}$ Neuroelectrics Corporation.

${ }^{4}$ Current affiliation: Department of Psychiatry, University of Minnesota

${ }^{+}$Corresponding author:

Laura Dubreuil-Vall

Laboratory for Neuropsychiatry and Neuromodulation

Massachusetts General Hospital

$14913^{\text {th }}$ St. $10^{\text {th }}$ floor.

Boston, MA 02129

Email: ldubreuilvall@mgh.harvard.edu

Phone: +1 6173906447

Keywords: ADHD, tDCS, EEG, ERP, Executive functions, DLPFC, state-dependencies

Number of words (excluding abstract, figures/tables, references, acknowledgments): 3245 
medRxiv preprint doi: https://doi.org/10.1101/2020.01.13.20017335; this version posted January 16, 2020. The copyright holder for this preprint (which was not certified by peer review) is the author/funder, who has granted medRxiv a license to display the preprint in

All rights reserved. No reuse allowed without permission.

\begin{abstract}
ADHD is a neurodevelopmental disorder associated with significant morbidity and mortality that affects $5 \%$ of children, adolescents and adults worldwide. Pharmacological and behavioral therapies exist, but critical symptoms such as dysexecutive deficits remain unaffected. In this randomized, placebo-controlled, double-blind, cross-over study we assess the cognitive and physiological effects of tDCS in adult ADHD patients in order to understand (1) the role of DLPFC laterality in ADHD dysexecutive deficits, (2) the physiological dynamics sustaining the modulation of executive function by tDCS, and (3) the impact of state-dependent dynamics of tDCS effect. The participants consisted of a random sample of 40 adult patients with a primary diagnosis of ADHD. Each patient performed three experimental sessions in which they received 30 minutes of $2 \mathrm{~mA}$ tDCS stimulation targeting the left DLPFC (anodal F3, cathodal Fp2), the right DLPFC (anodal F4, cathodal Fp1) and Sham. Before and after each session, half of the patients completed the Flanker task (EFT) and the other half performed the Stop Signal Task (SST), while we assessed cognitive (reaction time, accuracy) and neurophysiological measures (EEG EventRelated-Potentials). Results show that anodal tDCS to the left DLPFC modulated cognitive (reaction time) and physiological measures (P300 amplitude) in the Flanker task in a state-dependent manner, but there were no significant effects in the Stop Signal Reaction Time of the SST. We interpret these results as an improvement in interference cognitive control (captured by the EFT) but not in action cancellation (assessed by the SST), supporting the hypothesis of the existence of different impulsivity constructs with overlapping but distinct anatomical substrates and therapeutic strategies. We conclude that anodal tDCS over the left DLPFC using a simple bipolar montage has pro-cognitive effects in dysexecutive patients with ADHD associated with the modulation of physiological signatures of cognitive control (i.e. treatment target), supporting specific hypotheses and strategies for neuromodulation treatment development under an experimental therapeutics framework aiming to link target engagement (cognitive and physiological) with clinical benefit. In addition, we also provide empirical evidence supporting the value of the P200, N200 and P300 as cross-sectional biomarkers of cognitive performance across tasks. Last, we provide mechanistic support for the state-dependent nature of the effects of tDCS, highlighting the importance of controlling the neural states before and during stimulation as a relevant therapeutic strategy.
\end{abstract}


medRxiv preprint doi: https://doi.org/10.1101/2020.01.13.20017335; this version posted January 16, 2020. The copyright holder for this preprint (which was not certified by peer review) is the author/funder, who has granted medRxiv a license to display the preprint in

All rights reserved. No reuse allowed without permission.

\section{Introduction}

Attention-deficit hyperactivity disorder (ADHD) is associated with functional impairment and high morbidity and mortality in youth and adulthood ${ }^{1-3}$. Epidemiologic studies suggest that ADHD affects up to $5 \%$ of adults worldwide ${ }^{4-6}$. Pharmacological and behavioral therapies exist, but critical symptoms such as dysexecutive deficits persist despite current treatments ${ }^{7-9}$.

Transcranial Direct Current Stimulation (tDCS) is emerging as a promising tool in human neuroscience research and neuropsychiatric therapeutics ${ }^{10}$. Previous studies show that tDCS targeting the dorsolateral prefrontal cortex (DLPFC) modulates domains of executive function ${ }^{11,12}$, specifically those affected in ADHD ${ }^{13}$. None of these studies, however, combined behavioral and physiological measures.

The Eriksen Flanker Task (EFT) ${ }^{14}$ and the Stop Signal Task (SST) ${ }^{15}$ are well-established experimental tasks used to assess impaired executive functions in $\mathrm{ADHD}^{16,17}$. Although they both capture inhibitory control processes, the EFT primarily assesses interference cognitive control (the ability to resist or resolve distracting interference that is irrelevant to the task), while the SST measures action cancellation (the ability to suppress dominant, automatic, already initiated responses) ${ }^{18-20}$. Human electrophysiological studies assessing event related potentials (ERPs) have established relevant signatures of executive function during these tasks. Specifically, P200, N200, P300 and ERN/Pe (Error Related Negativity/Positivity) characterize the attentional and inhibitory functions that break down during conflict due to dysexecutive deficits and impulsivity ${ }^{21-24}$.

In this study, we tested 40 ADHD patients during three experimental visits and compared the effect of anodal tDCS targeting the left DLPFC vs. right DLPFC vs. Sham. Immediately before and after tDCS, half of the patients performed the EFT and the other half the SST, while we measured behavioral (reaction time and accuracy) and neurophysiological (ERPs) responses. The primary goal of the study was to empirically validate physiological biomarkers of dysexecutive deficits in adult ADHD, including response biomarkers (i.e. therapeutic targets), crosssectional diagnostic biomarkers) and physiological and behavioral baseline prognostic signatures characterizing state-dependent effects ${ }^{25}$. Our specific aims were to assess (1) the role of DLPFC laterality in ADHD deficits in interference cognitive control (EFT) and action cancellation (SST), (2) the physiological dynamics sustaining the modulation of executive function by tDCS and (3) the impact of state-dependent dynamics of tDCS effects.

\section{Methods and materials}


medRxiv preprint doi: https://doi.org/10.1101/2020.01.13.20017335; this version posted January 16, 2020. The copyright holder for this preprint (which was not certified by peer review) is the author/funder, who has granted medRxiv a license to display the preprint in

All rights reserved. No reuse allowed without permission.

A randomized, placebo-controlled, double-blind, cross-over study was performed at the Massachusetts General Hospital (Boston, USA). Recruitment started on July 2015 and ended on March 2018. The study was approved by the Partners Healthcare Institutional Review Board and registered on ClinicalTrials.gov (NCT04175028). The full protocol is available at Supplement 1.

\subsection{Participants}

Forty-four adult patients with a primary diagnosis of ADHD were recruited from the Division of Neuropsychiatry, the Behavioral Neurology Unit and the Adult ADHD Research Program at Massachusetts General Hospital and randomized (see Table S1 in Supplement 2 for demographic characteristics and medications). Patients between 18 and 67 years of age with a diagnosis of ADHD in adulthood were included, meeting the DSM$5^{26}$ criteria determined by semi-structured clinical interview (MINI International Neuropsychiatric Interview) and clinical questionnaires (Adult Self-Reported Scale, ASRS). Patients were either off stimulant medications or, if undergoing treatment with stimulants, were asked to discontinue two days prior to the experiment, under physicianguided protocol, and allowed to resume afterwards. Exclusion criteria consisted of current or past history of clinically unstable psychiatric conditions, pregnant or nursing females, and inability to participate in testing procedures or contraindications to tDCS. All participants gave informed and written consent for participation.

\subsection{Intervention}

For each session, $2 \mathrm{~mA}$ of anodal stimulation was applied for 30 minutes with $\mathrm{Ag} / \mathrm{AgCl}$ electrodes (contact area $3.14 \mathrm{~cm}^{2}$ ) using the hybrid tDCS-EEG Starstim ${ }^{\circledR}$ system (Neuroelectrics, USA, also used for EEG recording). The duration of the ramp-up and -down at the beginning and the end of the stimulation was set to 15 seconds. During the stimulation period the subject was instructed to sit and relax with eyes open.

The anodal electrode was placed on the scalp at the F4 (for Right DLPFC stimulation) or F3 (for Left DLPFC stimulation) positions, according to the international 10-20 EEG system (Figure S0 in Supplement 2). The cathode was placed in the contralateral supraorbital region (Fp1 or Fp2). For the sham condition, the electrodes were placed at the same positions but the current was applied only for the 15-second ramp up phase at the beginning and the end of a 30-minute sham-stimulation period, to simulate the potential experience of local tingling sensation that real stimulation produces but without sustained effect on cortical activity.

The order of stimulation was randomized by a computer-generated list. The experimenter and the subject 
medRxiv preprint doi: https://doi.org/10.1101/2020.01.13.20017335; this version posted January 16, 2020. The copyright holder for this preprint (which was not certified by peer review) is the author/funder, who has granted medRxiv a license to display the preprint in

All rights reserved. No reuse allowed without permission.

were blinded by using the double-blind mode in Starstim's software NIC, which blinds the user on the type of stimulation used (active tDCS targeting left/right DLPFC or sham) after a 4-digit password is introduced by the administrator.

\subsection{Outcomes}

Immediately before and after tDCS, half of the patients $(n=20)$ completed the EFT (Figure 2a), in which subjects must respond to the direction of a central arrow that is surrounded ("flanked") by distracting arrows that can either have the same (congruent trials) or opposing orientation (incongruent trials) as the central one. Participants were instructed to press the left or right arrow buttons following the direction of the central arrow, ignoring the flanker arrows. The accuracy of correct/incorrect responses and the reaction time (RT) for each stimulus were measured.

The other half of the patients $(\mathrm{n}=20$ ) performed the SST (Figure $2 \mathrm{~b}$ ), in which participants must press the right or left mouse button as quickly as possible when letters "Z" or "A" appear, respectively (Go-trial). However, whenever "A" or "Z" is followed by an "X" (the Stop Signal), which appears with varying adaptive delays from the Go stimulus, participants must withhold their response (Stop-trial). We measured the accuracy of correct/incorrect responses, the RT for Go-trials and the time it takes for the participant to withhold their response in the Stop-trials (Stop-Signal Reaction Time, SSRT).

During the tasks, EEG was recorded from 7 positions (Fp1, Fp2, F3, Fz, F4, P3 and P4) with $\mathrm{Ag} / \mathrm{AgCl}$ electrodes at a sampling frequency of 500 samples/second. EEG data was referenced to the right mastoid. Offline processing was then performed using EEGlab (version 13.5.4b) ${ }^{27}$. Independent component analysis (ICA) was utilized to identify and remove activity associated with blinks, eye movements, and other artifacts. Data was filtered from 1 to $20 \mathrm{~Hz}$ to remove non-neural physiological activity (skin/sweat potentials) and noise from electrical outlets. Trials were epoched within a time frame of $200 \mathrm{~ms}$ before and $800 \mathrm{~ms}$ after the stimulus onset. The mean of the pre-stimulus baseline $[-200,0] \mathrm{ms}$ was then subtracted from the entire ERP waveform for each epoch to eliminate any voltage offset. After rejecting trials that had at least a sample above $+/-150 \mathrm{uV}$, the remaining trials were averaged for each time point and stimulation condition.

\subsection{Statistical analysis}

Based on similar studies ${ }^{12,28}$, we estimated a sample size of 20 subjects for each block of tasks to provide 
medRxiv preprint doi: https://doi.org/10.1101/2020.01.13.20017335; this version posted January 16, 2020. The copyright holder for this preprint (which was not certified by peer review) is the author/funder, who has granted medRxiv a license to display the preprint in

All rights reserved. No reuse allowed without permission.

$85 \%$ power to detect an effect size of $\mathrm{d}=0.6(\alpha=5 \%), 25$ subjects would provide XX\% power and 30 subjects YY $\%$ power for the same estimated effect size and $\alpha=5 \%$. We estimated a $20 \%$ attrition rate based on previous studies.

The RT and the ERP amplitudes were introduced into Generalized Linear Models with Mixed Effects (GLMM) modeled using the glmer and lmer functions of the lme4 package ${ }^{29}$ in R software (v1.0.136) ${ }^{30}$ (see Tables S2-S7 in Supplement 2 for expanded details). A Gamma distribution was used for the RT, a binomial distribution was used for the accuracy of correct responses and a Gaussian distribution was used to model the ERP amplitudes (see Supplement 2 for more details). Correction for multiple comparisons was applied using the 'mvt' method $^{31}$ from the lsmeans package in $\mathrm{R}$, which produces the same adjustments as the Tukey method but using Monte-Carlo simulations $^{31}$. Coefficients were considered significant when $\mathrm{p}<0.05$ (two-tailed).

For the Stop-trials of the SST, the mean SSRT was calculated by subtracting the mean Stop Signal Delay (SSD: the time it takes for the Stop Signal to appear after the "A" or "Z" stimuli) from the mean RT of Go-trials ${ }^{32}$. The mean SSRT was then analyzed using a standard ANOVA model with the Stimulation type (Left/Right/Sham) and the TimePoint (PRE/POST) as factors.

ERP analysis focused on P200, N200 and P300 amplitudes for incongruent EFT trials and SST Stop-trials, and P200 in congruent EFT trials and SST Go-trials (as congruent and Go-trials do not show N200 and P300). ERN and Pe were also analyzed in both tasks for trials with incorrect responses. After visual inspection of the grand average waveforms, the mean ERP amplitude of each single trial was calculated in a specific time-window centered in the peak latency of the grand average waveforms. Mean amplitudes were then introduced into a linear model with mixed effects (LMM) and a normal distribution. ERP analysis focused on the average of F3, Fz and F4 positions.

For state-dependencies, the RT and the amplitude of P200, N200 and P300 were computed separately for real tDCS and Sham. Beta coefficients were modeled with a linear model with mixed effects (LMM), with the difference from PRE to POST stimulation as the dependent variable and the mean of the same (or another) variable at baseline as an independent factor. P values were corrected for multiple comparisons using the False Discovery Rate (FDR) method.

\section{Results}

As shown in Figure 1, 37 patients were included in the analysis: 18 in the EFT group and 19 in the SST group. Attrition rate was lower than anticipated. No important harms or unintended side effects were reported. 
medRxiv preprint doi: https://doi.org/10.1101/2020.01.13.20017335; this version posted January 16, 2020. The copyright holder for this preprint (which was not certified by peer review) is the author/funder, who has granted medRxiv a license to display the preprint in

All rights reserved. No reuse allowed without permission.

\section{$\underline{3.1 \text { Flanker task }}$}

\subsubsection{Cognitive results}

For incongruent trials, left-sided stimulation led to a significantly faster RT compared to Sham $(\beta=-16.1 \mathrm{~ms}$, $\mathrm{CI}=[-22.8,-9.3], \mathrm{p}<0.0001)$, while right-sided stimulation did not have any significant effect $(\beta=-5.3 \mathrm{~ms}, \mathrm{CI}=[-13.7$, 3.1], $\mathrm{p}=0.390$ ) (Figure 3a). The effect of left-sided stimulation was also greater than that of right-sided stimulation $(\beta=10.7 \mathrm{~ms}, \mathrm{CI}=[1.26,20.2], \mathrm{p}=0.0183)$. For congruent trials there were no significant changes for any of the stimulation conditions (Figure S1a in Supplement 2). None of the stimulation conditions lead to significant changes in accuracy compared to Sham, both for incongruent and congruent trials (Figure $3 \mathrm{~b}$ and S1b).

\subsubsection{Event-Related Potentials}

Both left-sided stimulation $(\beta=2.15 \mu \mathrm{V}, \mathrm{CI}=[0.31,3.99], \mathrm{p}=0.022)$ and right-sided stimulation $(\beta=2.37 \mu \mathrm{V}$, $\mathrm{CI}=[0.53,4.20], \mathrm{p}=0.011)$ led to a significant $\mathrm{P} 300$ amplitude increase compared to Sham for incongruent trials (Figure 3c).

There are no significant changes in N200 after left-sided or right-sided stimulation compared to Sham, but the reduction in N200 amplitude after left-sided stimulation is significantly different compared to right-sided stimulation $(\beta=-2.43 \mu \mathrm{V}, \mathrm{CI}=[-4.64,-0.22], \mathrm{p}=0.027)$. Note that most $\mathrm{P} 200, \mathrm{~N} 200$ and $\mathrm{P} 300$ amplitude changes occurred primarily around the area of the anodal stimulation electrode (F3 or F4), matching the laterality of the stimulation, especially for left-sided stimulation (Figure 3d).

There were no significant changes in P200 amplitude for incongruent (Figure 3b) or congruent (Figure S3a in Supplement 2) trials. ERN and Pe did not show significant differences either (Figure S3b in Supplement 2).

\subsubsection{ERP cross-correlation with reaction time}

The amplitudes of P200, N200 and P300 were significantly correlated with RT for incongruent trials in a cross-sectional trial-by-trial basis: the greater $\mathrm{P} 200(\beta=-0.26 \mathrm{~ms} / \mu \mathrm{V}, \mathrm{CI}=[-0.43,-0.09], \mathrm{p}=0.002)$ and $\mathrm{P} 300$ amplitudes $(\beta=-0.25 \mathrm{~ms} / \mu \mathrm{V}, \mathrm{CI}=[-0.50,-0.04], \mathrm{p}=0.046)$ the faster the $\mathrm{RT}$, and the smaller the $\mathrm{N} 200$ amplitude the faster the RT $(\beta=-0.54 \mathrm{~ms} / \mu \mathrm{V}, \mathrm{CI}=[-0.79,-0.29], \mathrm{p}<0.0001)$.

\subsubsection{State-dependencies}


medRxiv preprint doi: https://doi.org/10.1101/2020.01.13.20017335; this version posted January $16,2020$. The copyright holder for this preprint (which was not certified by peer review) is the author/funder, who has granted medRxiv a license to display the preprint in

All rights reserved. No reuse allowed without permission.

Table S8 in Supplement 2 shows the effect of variables at baseline (before stimulation) on the change on the same (and other) variables after stimulation (i.e. state-dependent relationships). Figure 5 shows the scatter plots of the significant predictors. The change in P300 and P200 after stimulation is conditioned by the amplitude of P300 and P200 at baseline, while the change in N200 is conditioned by the amplitude of N200 and P300 at baseline.

\subsection{Stop Signal Task}

\subsubsection{Cognitive results}

The RT for Go-trials significantly increased after Left stimulation compared to sham $(\beta=8.32 \mu \mathrm{V}, \mathrm{CI}=[2.18,14.47]$, $\mathrm{p}=0.0044)$ (Figure 4a), but there were no significant changes in the SSRT for Stop-trials (Figure 4b). There were also no significant changes in accuracy for any of the stimulation conditions and for none of the trial types (Figure S4 in Supplement 2).

\subsubsection{Event-Related Potentials}

For Go-trials, P200 amplitude significantly increased after Left stimulation compared to Sham $(\beta=0.51 \mathrm{uV}$, $\mathrm{CI}=[0.09,0.92], \mathrm{p}=0.0160$ ) (Figure 4c). For Stop-trials, there were no significant changes in P200, N200 and P300 (Figure 4d). There were no significant changes in ERN or Pe (Figure S5 in Supplement 2).

\subsubsection{ERP cross-correlation with reaction time}

The amplitude of P200 was also significantly correlated with RT for Go-trials, i.e., the greater P200 amplitude, the slower the $\mathrm{RT}(\beta=1.08 \mathrm{~ms} / \mu \mathrm{V}, \mathrm{CI}=[0.69,1.47], \mathrm{p}<0.001)$.

\subsubsection{State-dependencies}

No significant state-dependencies were found for the SST (Table S8 in Supplement 2).

\section{Discussion}

To the best of our knowledge, this is the first study with ADHD patients to assess the lateralized effects of anodal tDCS to the left and right DLPFC combining cognitive with physiological measures of executive function, using different inhibitory control tasks, quantifying state-dependent dynamics and assessing cross-sectional 
medRxiv preprint doi: https://doi.org/10.1101/2020.01.13.20017335; this version posted January 16, 2020. The copyright holder for this preprint (which was not certified by peer review) is the author/funder, who has granted medRxiv a license to display the preprint in

All rights reserved. No reuse allowed without permission.

physiological biomarkers.

\subsection{Flanker Task}

Our results confirmed that anodal tDCS targeting the DLPFC improves RT in the EFT in ADHD patients, similarly to what we previously described in healthy subjects ${ }^{12}$. Specifically, we describe that anodal tDCS targeting the left DLPFC results in a significant reduction in RT in incongruent trials, compared to a non-significant change after sham or right DLPFC anodal modulation. Compared to our previous study with HC, the baseline RT (before stimulation) is slower in ADHD patients and the size effect of the improvement in RT after left-sided stimulation is larger for ADHD $(\beta=-16.1 \mathrm{~ms})$ than for $\mathrm{HC}(\beta=-8.37 \mathrm{~ms})$.

The faster RT of incongruent trials in ADHD patients is correlated with a significant increase in P300 amplitude, in this case for both left- and right-sided anodal tDCS. Larger P300 amplitudes are associated with effective conflict post-processing and cognitive control, with the subsequent behavioral inhibition of incorrect prepotent responses ${ }^{22,33,34}$. We thus interpret the increase in P300 amplitude as a modulation of conflict resolution and interference control processes, leading to more efficient inhibition of distractors and competing responses (i.e., faster RT). Given that P300 increases significantly after left-sided and right-sided stimulation, but behavior (RT) only changes after left-sided stimulation, we hypothesize that the physiological effect of right-sided stimulation is not sufficient to trigger a significant behavioral change, suggesting a greater role for the left DLPFC in the modulation of executive function.

Although in previous research with healthy controls we found a significant decrease in N200 amplitude after left stimulation ${ }^{12}$, indicative of an improvement in selective attention in a context of conflict resolution, in the current study the decrease in N200 amplitude was not significant compared to Sham. This highlights the need to better understand the underlying physiological differences between ADHD patients and healthy subjects leading to different tDCS effects.

\subsection{Stop Signal Task}

In the SST, proactive inhibition is defined as the advanced preparation to halt action in the anticipation of an imminent Stop Signal in Go-trials, requiring greater selective attention in the visual search for the Stop Signal to appear. Reactive inhibition is defined as the performance of outright stopping in response to the appearance of a Stop Signal in Stop-trials ${ }^{35}$. In the current study we found that tDCS to the left DLPFC leads to a significant 
medRxiv preprint doi: https://doi.org/10.1101/2020.01.13.20017335; this version posted January 16, 2020. The copyright holder for this preprint (which was not certified by peer review) is the author/funder, who has granted medRxiv a license to display the preprint in

All rights reserved. No reuse allowed without permission.

increase on the time patients withhold their response in Go-trials waiting for the Stop Signal to appear, which is correlated with a significant increase in P200 amplitude. There is a wide range and diversity of factors that have been found to affect the characteristics of the P200, but its amplitude is generally associated with selective attention to visual stimuli ${ }^{36}$. We thus interpret the increase in P200 amplitude as a modulation in selective attention when searching for the Stop Signal to appear, with the subsequent improvement in proactive inhibition. However, the lack of significant changes in the SSRT suggests no effects on reactive inhibition. Although there have been positive results in tDCS studies using the SST in a healthy population targeting other areas like the right inferior frontal gyrus ${ }^{37-42}$, previous tDCS studies with ADHD patients using the SST and targeting the DLPFC have also found a lack of significant effects on the SSRT and accuracy ${ }^{28,43}$. These results support the formulation of inhibitory control and impulsivity as complex multimodal processes with subdomain specificity (e.g. impulsivity of thought, action, affect, etc.) captured by different experimental tasks and with different anatomical representation ${ }^{44}$. These findings confirm the hypothesis that that there is a dissociation between action cancellation or the ability of suppressing prepotent responses that have already been initiated, captured by the SST, and interference cognitive control or the ability of resisting distractors and resolving interference between competing responses, captured by the EFT ${ }^{20,45-50}$. From a translational perspective, this also implies that the DLPFC may be a good substrate to improve interference cognitive control and proactive inhibition, but if the goal is to improve action cancellation (e.g. tics, compulsions) one should consider alternative windows into the circuitry ${ }^{19,44}$.

\section{$\underline{4.3 \text { Cross-sectional biomarkers }}$}

Our findings indicate that the amplitude of P200, N200 and P300 on a trial-by-trial basis is correlated crosssectionally with RT in the EFT (as previously described in healthy subjects ${ }^{12}$ ) and the SST, thus supporting the interpretation of the observed tDCS effects (i.e. small N200 and large P300 are associated with more adaptive responses thus changes in this direction should be therapeutic) and highlighting their value as a potential diagnostic, monitoring or surrogate biomarker ${ }^{25}$ for cognitive performance.

\subsection{State-dependence}

Smaller N200 and greater P300 amplitudes are associated with better cognitive performance ${ }^{21,33}$, therefore decreases in N200 and increases in P300 can be interpreted as improvements. Our findings indicate that the more maladaptive the baseline ERP amplitude, the greater the improvement after tDCS in the EFT. The state-dependent 
medRxiv preprint doi: https://doi.org/10.1101/2020.01.13.20017335; this version posted January 16, 2020. The copyright holder for this preprint (which was not certified by peer review) is the author/funder, who has granted medRxiv a license to display the preprint in

All rights reserved. No reuse allowed without permission.

characteristics of tDCS have important implications for treatment development: beyond stimulation parameters, clinical trials may benefit from controlling patients' baseline state (before or during stimulation) to minimize response variability and maximize the therapeutic effects of tDCS.

\section{$\underline{4.3 \text { Limitations }}$}

While the field has established differences between the constructs captured by the EFT and the SST, the nomenclature used to define the overlap and differences at the cognitive and behavioral level remain equivocal and often contradictory. This seems more than a simple problem with semantics and reflects deficits in the core formulation of the subtleties across executive constructs. We have opted for descriptive terms previously used in the literature (e.g. interference cognitive control and action cancellation), but acknowledge that other terminologies may be considered.

\section{$\underline{4.4 \text { Conclusions }}$}

This study indicates that anodal tDCS over the left DLPFC using a simple bipolar montage has pro-cognitive effects in dysexecutive patients with ADHD associated with the modulation of physiological signatures of cognitive control (i.e. treatment target), supporting specific hypotheses and strategies for neuromodulation treatment development under an experimental therapeutics framework aiming to link target engagement (cognitive and physiological) with clinical benefit. In addition, we provide mechanistic support for the state-dependent nature of the effects of tDCS, highlighting the importance of controlling (or at least measuring) the neural states before (and possibly during) stimulation as a relevant therapeutic strategy beyond choices regarding the neuromodulation parameter space. We also provide empirical evidence supporting the value of the P200, N200 and P300 as crosssectional biomarkers of cognitive performance across tasks, and across populations if taken together with our previous similar report in healthy subjects ${ }^{12}$. Last, we interpret these results as an improvement in interference cognitive control (captured by the EFT) but not in action cancellation (assessed by the SST), supporting the hypothesis of the existence of different impulsivity constructs with overlapping but distinct anatomical substrates and therapeutic strategies.

\section{Acknowledgements}

This research was partly supported by NIH grants (RO1 MH112737, R21 DA042271, R21 AG056958 and R21 
medRxiv preprint doi: https://doi.org/10.1101/2020.01.13.20017335; this version posted January 16, 2020. The copyright holder for this preprint (which was not certified by peer review) is the author/funder, who has granted medRxiv a license to display the preprint in All rights reserved. No reuse allowed without permission.

MH115280) to JAC.

Contributions

JAC designed the study; AV, FGB and PC acquired the data; LDV, GR, ASW, JAC analyzed the data; LDV, CS, ASW and JAC wrote the manuscript.

\section{Disclosures}

GR is a co-founder of Neuroelectrics, a company that manufactures the tDCS technology used in the study. LDV is an employee at Neuroelectrics. JAC is a member of the scientific advisory board for Apex Neuroscience Inc. AW has patent applications pending related to cognitive enhancement through brain stimulation and new methods of transcranial electrical stimulation. CS reports that, within the past 12 months, he has received research support from Shire/Takeda Pharmaceuticals, has served as a consultant to Adlon, Shire, Sunovion, Supernus and Teva pharmaceuticals, and has received book royalties for "Fast Minds - How to Thrive If You Have ADHD [or Think You Might]," as well as "ADHD in Adults - A Practical Guide to Evaluation and Management". The remaining authors declare no competing financial interests. 
medRxiv preprint doi: https://doi.org/10.1101/2020.01.13.20017335; this version posted January 16, 2020. The copyright holder for this preprint (which was not certified by peer review) is the author/funder, who has granted medRxiv a license to display the preprint in

All rights reserved. No reuse allowed without permission.

\section{References}

1. Biederman J, Faraone SV, Spencer T, Wilens T, Mick E, Lapey KA. Gender differences in a sample of adults with attention deficit hyperactivity disorder. Psychiatry research. 1994;53(1):13-29.

2. Murphy K, Barkley RA. Attention deficit hyperactivity disorder adults: comorbidities and adaptive impairments. Comprehensive psychiatry. 1996;37(6):393-401.

3. Faraone SV, Biederman J, Spencer T, et al. Attention-deficit/hyperactivity disorder in adults: an overview. Biol Psychiatry. 2000;48(1):9-20.

4. Kessler RC, Adler L, Barkley R, et al. The prevalence and correlates of adult ADHD in the United States: results from the National Comorbidity Survey Replication. The American journal of psychiatry. 2006;163(4):716-723.

5. Polanczyk G, de Lima MS, Horta BL, Biederman J, Rohde LA. The worldwide prevalence of ADHD: a systematic review and metaregression analysis. The American journal of psychiatry. 2007;164(6):942-948.

6. Fayyad J, De Graaf R, Kessler R, et al. Cross-national prevalence and correlates of adult attention-deficit hyperactivity disorder. The British journal of psychiatry : the journal of mental science. 2007;190:402-409.

7. Biederman J, Petty C, Fried R, et al. Impact of psychometrically defined deficits of executive functioning in adults with attention deficit hyperactivity disorder. The American journal of psychiatry. 2006;163(10):1730-1738.

8. Brown TE, Landgraf JM. Improvements in executive function correlate with enhanced performance and functioning and health-related quality of life: evidence from 2 large, double-blind, randomized, placebo-controlled trials in ADHD. Postgraduate medicine. 2010;122(5):42-51.

9. Biederman J, Mick E, Fried R, Wilner N, Spencer TJ, Faraone SV. Are stimulants effective in the treatment of executive function deficits? Results from a randomized double blind study of OROS-methylphenidate in adults with ADHD. European neuropsychopharmacology : the journal of the European College of Neuropsychopharmacology. 2011;21(7):508-515.

10. Philip NS, Nelson BG, Frohlich F, Lim KO, Widge AS, Carpenter LL. Low-Intensity Transcranial Current Stimulation in Psychiatry. The American journal of psychiatry. 2017;174(7):628-639.

11. Sarkis RA, Kaur N, Camprodon JA. Transcranial Direct Current Stimulation (tDCS): Modulation of Executive Function in Health and Disease. Current Behavioral Neuroscience Reports. 2014;1(2):74-85.

12. Dubreuil-Vall L, Chau P, Ruffini G, Widge AS, Camprodon JA. tDCS to the left DLPFC modulates cognitive and physiological correlates of executive function in a state-dependent manner. Brain Stimulation. 2019.

13. Rubia K. Cognitive Neuroscience of Attention Deficit Hyperactivity Disorder (ADHD) and Its Clinical Translation. Frontiers in Human Neuroscience. 2018;12:100. 
medRxiv preprint doi: https://doi.org/10.1101/2020.01.13.20017335; this version posted January 16, 2020. The copyright holder for this preprint (which was not certified by peer review) is the author/funder, who has granted medRxiv a license to display the preprint in

All rights reserved. No reuse allowed without permission.

14. Eriksen BA, Eriksen CW. Effects of noise letters upon the identification of a target letter in a nonsearch task. Perception \& Psychophysics. 1974;16(1):143-149.

15. Lappin J, Eriksen C. Use of a delayed signal to stop a visual reaction-time response. Journal of Experimental Psychology. 1966;72:805-811.

16. Mullane JC, Corkum PV, Klein RM, McLaughlin E. Interference control in children with and without ADHD: A systematic review of Flanker and Simon task performance. Child Neuropsychology. 2009;15(4):321-342.

17. Alderson RM, Rapport MD, Kofler MJ. Attention-deficit/hyperactivity disorder and behavioral inhibition: a metaanalytic review of the stop-signal paradigm. Journal of abnormal child psychology. 2007;35(5):745-758.

18. Logan GD, Van Zandt T, Verbruggen F, Wagenmakers EJ. On the ability to inhibit thought and action: general and special theories of an act of control. Psychological review. 2014;121(1):66-95.

19. Boisseau CL, Thompson-Brenner H, Caldwell-Harris C, Pratt E, Farchione T, Barlow DH. Behavioral and cognitive impulsivity in obsessive-compulsive disorder and eating disorders. Psychiatry research. 2012;200(2-3):1062-1066.

20. Verbruggen F, Logan GD. Response inhibition in the stop-signal paradigm. Trends in cognitive sciences. 2008;12(11):418-424.

21. Danielmeier C, Wessel JR, Steinhauser M, Ullsperger M. Modulation of the error-related negativity by response conflict. Psychophysiology. 2009;46(6):1288-1298.

22. Clayson PE, Larson MJ. Conflict adaptation and sequential trial effects: support for the conflict monitoring theory. Neuropsychologia. 2011;49(7):1953-1961.

23. Larson MJ, Clayson PE, Clawson A. Making sense of all the conflict: A theoretical review and critique of conflictrelated ERPs. International Journal of Psychophysiology. 2014;93(3):283-297.

24. Falkenstein M, Hoormann J, Christ S, Hohnsbein J. ERP components on reaction errors and their functional significance: a tutorial. Biol Psychol. 2000;51(2-3):87-107.

25. Food and Drug Administration (US). FDA-NIH Biomarker Working Group. BEST (Biomarkers, EndpointS, and other Tools) Resource [Internet]. Silver Spring (MD), Co-published by National Institutes of Health (US), Bethesda (MD). https://www.ncbi.nlm.nih.gov/books/NBK326791/. Published 2016. Accessed.

26. American-Psychiatric-Association. The Diagnostic and Statistical Manual of Mental Disorders. 5th Edition ed: American Psychiatric Publishing; 2013.

27. Delorme A, Makeig S. EEGLAB: an open source toolbox for analysis of single-trial EEG dynamics including independent component analysis. J Neurosci Methods. 2004;134(1):9-21.

28. Allenby C, Falcone M, Bernardo L, et al. Transcranial direct current brain stimulation decreases impulsivity in ADHD. Brain Stimulation. 2018;11(5):974-981. 
medRxiv preprint doi: https://doi.org/10.1101/2020.01.13.20017335; this version posted January 16, 2020. The copyright holder for this preprint (which was not certified by peer review) is the author/funder, who has granted medRxiv a license to display the preprint in

All rights reserved. No reuse allowed without permission.

29. Bates D, Mächler M, Bolker B, Walker S. Fitting Linear Mixed-Effects Models Using lme4. Journal of Statistical Software; Vol 1, Issue 1 (2015). 2015.

30. A language and environment for statistical computing [computer program]. R Foundation for Statistical Computing, Vienna, Austria; 2017.

31. Lenth RV. Least-Squares Means: The R Package 1smeans. Journal of Statistical Software; Vol 1, Issue 1 (2016). 2016.

32. Eagle DM, Baunez C, Hutcheson DM, Lehmann O, Shah AP, Robbins TW. Stop-Signal Reaction-Time Task Performance: Role of Prefrontal Cortex and Subthalamic Nucleus. Cerebral Cortex. 2008;18(1):178-188.

33. Clayson PE, Larson MJ. Effects of repetition priming on electrophysiological and behavioral indices of conflict adaptation and cognitive control. Psychophysiology. 2011;48(12):1621-1630.

34. Enriquez-Geppert S, Konrad C, Pantev C, Huster RJ. Conflict and inhibition differentially affect the N200/P300 complex in a combined go/nogo and stop-signal task. Neuroimage. 2010;51(2):877-887.

35. Castro-Meneses LJ, Johnson BW, Sowman PF. The effects of impulsivity and proactive inhibition on reactive inhibition and the go process: insights from vocal and manual stop signal tasks. Front Hum Neurosci. 2015;9:529.

36. Philips S, Takeda Y. An EEG/ERP study of efficient versus inefficient visual search. Proceedings of the Annual Meeting of the Cognitive Science Society. 2009; Volume 31.

37. Hogeveen J, Grafman J, Aboseria M, David A, Bikson M, Hauner KK. Effects of High-Definition and Conventional tDCS on Response Inhibition. Brain Stimul. 2016;9(5):720-729.

38. Cunillera T, Fuentemilla L, Brignani D, Cucurell D, Miniussi C. A simultaneous modulation of reactive and proactive inhibition processes by anodal tDCS on the right inferior frontal cortex. PLoS One. 2014;9(11):e113537.

39. Ditye T, Jacobson L, Walsh V, Lavidor M. Modulating behavioral inhibition by tDCS combined with cognitive training. Experimental brain research. 2012;219(3):363-368.

40. Jacobson L, Javitt DC, Lavidor M. Activation of inhibition: diminishing impulsive behavior by direct current stimulation over the inferior frontal gyrus. J Cogn Neurosci. 2011;23(11):3380-3387.

41. Cai Y, Li S, Liu J, et al. The Role of the Frontal and Parietal Cortex in Proactive and Reactive Inhibitory Control: A Transcranial Direct Current Stimulation Study. J Cogn Neurosci. 2016;28(1):177-186.

42. Stramaccia DF, Penolazzi B, Sartori G, Braga M, Mondini S, Galfano G. Assessing the effects of tDCS over a delayed response inhibition task by targeting the right inferior frontal gyrus and right dorsolateral prefrontal cortex. Experimental brain research. 2015;233(8):2283-2290.

43. Cosmo C, Baptista AF, de Araujo AN, et al. A Randomized, Double-Blind, Sham-Controlled Trial of Transcranial Direct Current Stimulation in Attention-Deficit/Hyperactivity Disorder. PLoS One. 2015;10(8):e0135371. 
medRxiv preprint doi: https://doi.org/10.1101/2020.01.13.20017335; this version posted January 16, 2020. The copyright holder for this preprint (which was not certified by peer review) is the author/funder, who has granted medRxiv a license to display the preprint in

All rights reserved. No reuse allowed without permission.

44. Bari A, Robbins TW. Inhibition and impulsivity: behavioral and neural basis of response control. Progress in neurobiology. 2013;108:44-79.

45. Verbruggen F, Liefooghe B, Notebaert W, Vandierendonck A. Effects of stimulus-stimulus compatibility and stimulus-response compatibility on response inhibition. Acta psychologica. 2005;120(3):307-326.

46. Verbruggen F, Liefooghe B, Vandierendonck A. The interaction between stop signal inhibition and distractor interference in the flanker and Stroop task. Acta psychologica. 2004;116(1):21-37.

47. Friedman NP, Miyake A. The relations among inhibition and interference control functions: a latent-variable analysis. Journal of experimental psychology General. 2004;133(1):101-135.

48. Aron AR, Robbins TW, Poldrack RA. Inhibition and the right inferior frontal cortex. Trends in cognitive sciences. 2004;8(4):170-177.

49. Derrfuss J, Brass M, von Cramon DY. Cognitive control in the posterior frontolateral cortex: evidence from common activations in task coordination, interference control, and working memory. Neuroimage. 2004;23(2):604-612.

50. Chambers CD, Bellgrove MA, Gould IC, et al. Dissociable mechanisms of cognitive control in prefrontal and premotor cortex. Journal of neurophysiology. 2007;98(6):3638-3647. 
medRxiv preprint doi: https://doi.org/10.1101/2020.01.13.20017335; this version posted January 16, 2020. The copyright holder for this preprint (which was not certified by peer review) is the author/funder, who has granted medRxiv a license to display the preprint in perpetuity.

All rights reserved. No reuse allowed without permission.

Figures and Tables

Block I: EFT group (2015-2017)

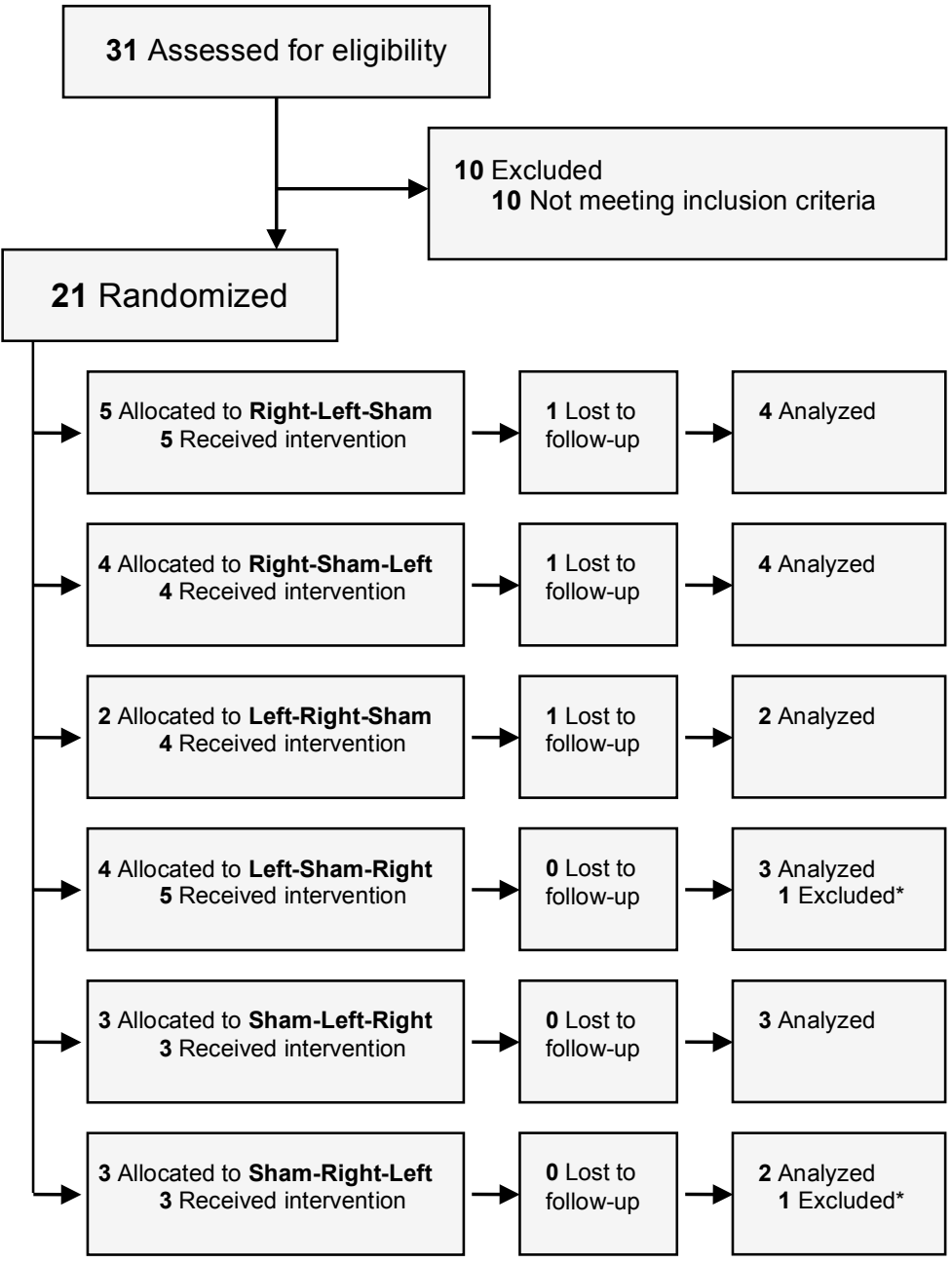

Block II: SST group (2017-2018)

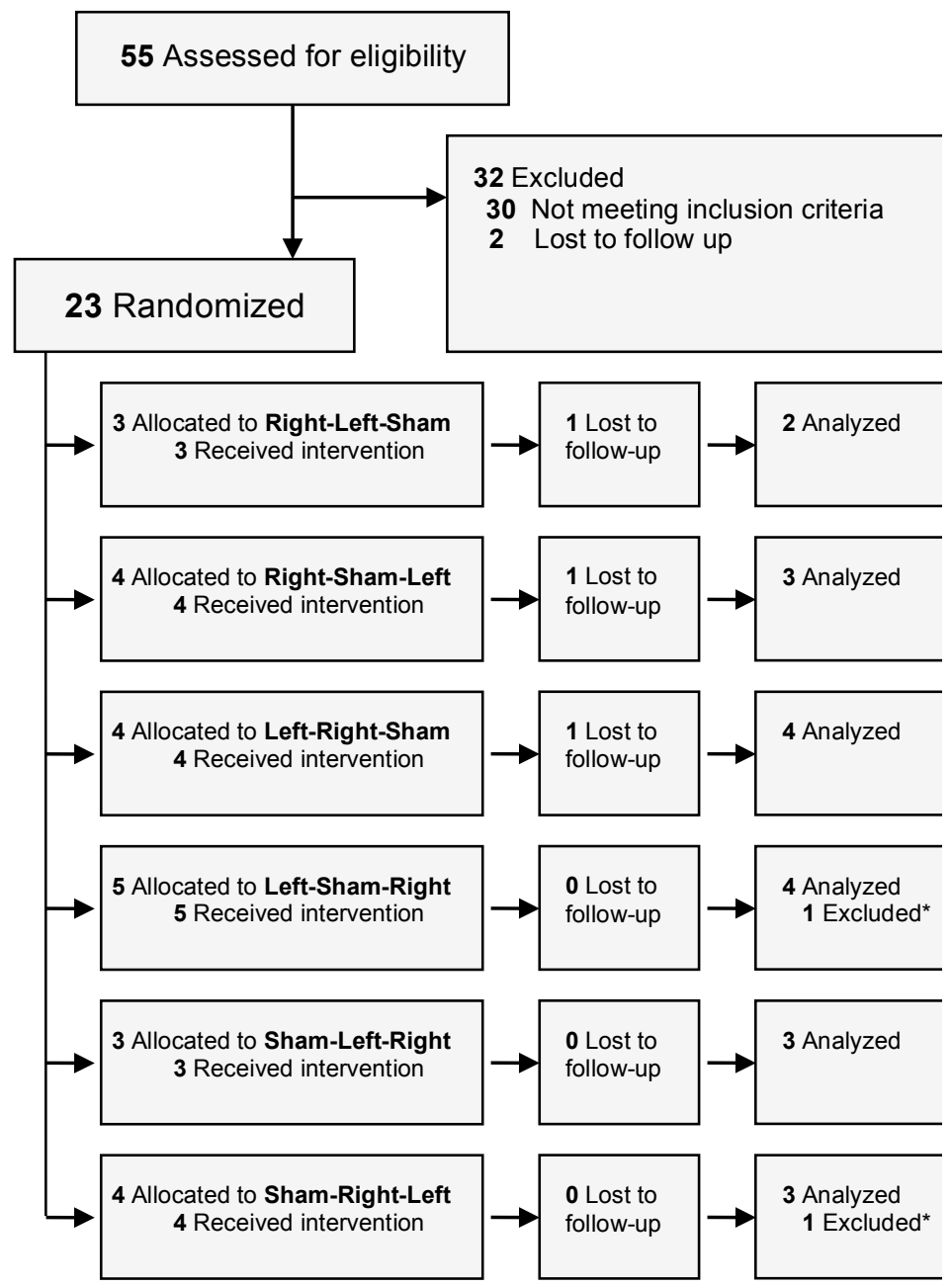

*Patients excluded from the analysis due to extreme movement artifacts in the EEG data that made the datasets unusable.

Figure 1. CONSORT Diagram 
medRxiv preprint doi: https://doi.org/10.1101/2020.01.13.20017335; this version posted January 16, 2020. The copyright holder for this preprint (which was not certified by peer review) is the author/funder, who has granted medRxiv a license to display the preprint in perpetuity.

All rights reserved. No reuse allowed without permission.

a)

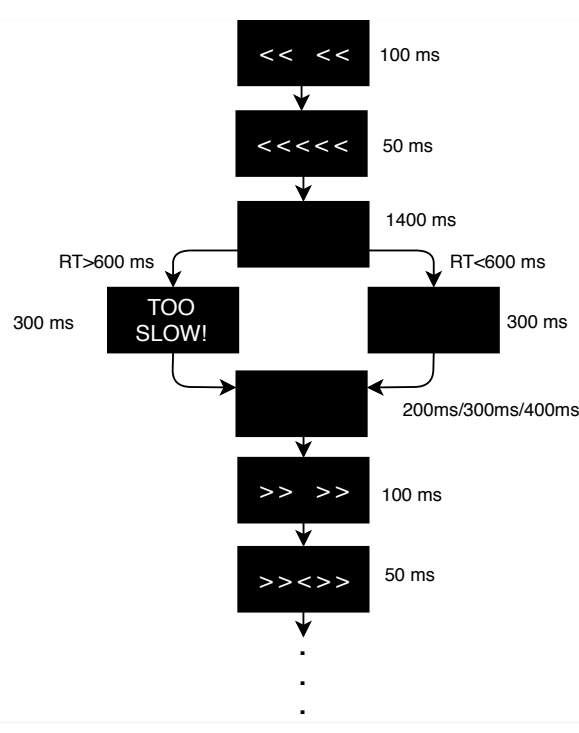

b)

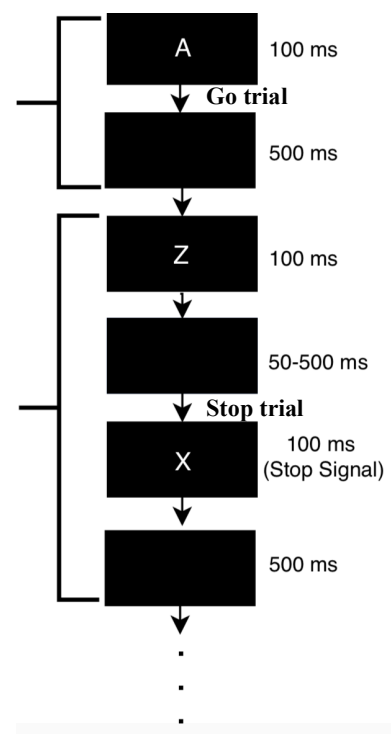

Figure 2. Flanker and Stop Signal task scheme. a) The Flanker task consisted of 140 trials in two blocks of 70 . Each subject had a different, fully random sequence of congruent and incongruent trials, with 2 congruent trials for each incongruent trial, in order to build a tendency towards congruent responses and thus increase the difficulty of conflict detection in incongruent trials. The task had a total duration of $10 \mathrm{~min}$, with 1 minute of training before the task started. The flanker arrows were first presented alone for duration of $136 \mathrm{~ms}, 114 \mathrm{~ms}, 92 \mathrm{~ms}, 70 \mathrm{~ms}$ or $48 \mathrm{~ms}$, and were then joined by the target arrow for $62 \mathrm{~ms}$, $52 \mathrm{~ms}$, $42 \mathrm{~ms}, 32 \mathrm{~ms}$ or $22 \mathrm{~ms}$, respectively (values were adjusted to the pyschometric "sweet spot" in which each patient achieved a performance in the range of 80-85\%). Stimulus presentation was followed by a black screen for 500 ms. The time-window for participants' response was $600 \mathrm{~ms}$ after target onset. If the participant did not respond within the response window, a screen reading 'TOO SLOW!' was presented for $300 \mathrm{~ms}$. Participants were told that if they saw this screen, they should speed up. If a response was made before the deadline, the 'TOO SLOW!' screen was omitted, and the black screen remained on screen for the $300 \mathrm{~ms}$ interval. Finally, each trial ended with presentation of the fixation cross for an additional randomly chosen duration $(200,300$ or $400 \mathrm{~ms})$ in order to avoid any habituation or expectation by the subject. Thus, trial durations varied between 1070-1400 ms. b) The SST consisted of 160 Go-trials (80\%) and 40 Stop-trials (20\%). The "A" or "Z" stimuli were first presented for $100 \mathrm{~ms}$ and they were followed by a black screen for $500 \mathrm{~ms}$. For the Stop-trials, the Stop Signal initially appeared $400 \mathrm{~ms}$ after the "A" or "Z", and was adjusted dynamically according to the subject's performance, increasing or decreasing by $50 \mathrm{~ms}$ respectively after a successful or unsuccessful answer, within a range of 50 to $500 \mathrm{~ms}$ in order to yield approximately $50 \%$ successful inhibition of the Stop-trials. 
medRxiv preprint doi: https://doi.org/10.1101/2020.01.13.20017335; this version posted January 16, 2020. The copyright holder for this preprint (which was not certified by peer review) is the author/funder, who has granted medRxiv a license to display the preprint in perpetuity.

All rights reserved. No reuse allowed without permission.

a)

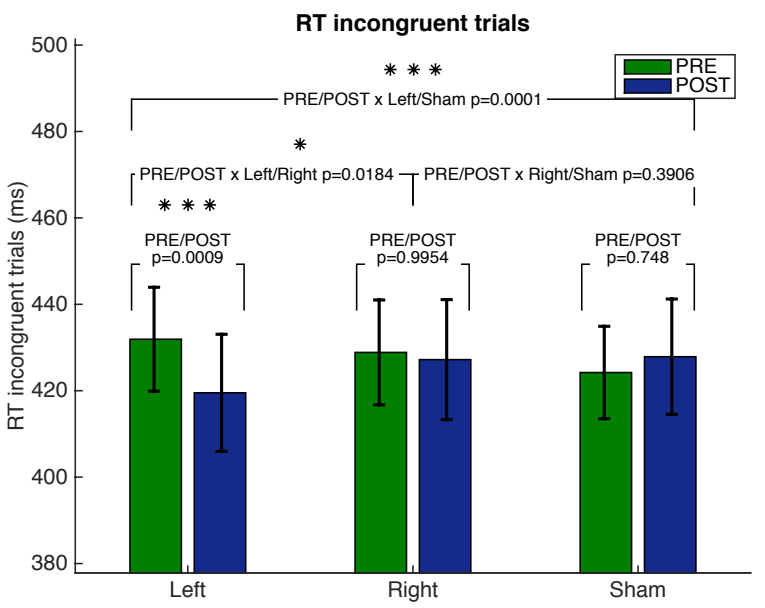

b)

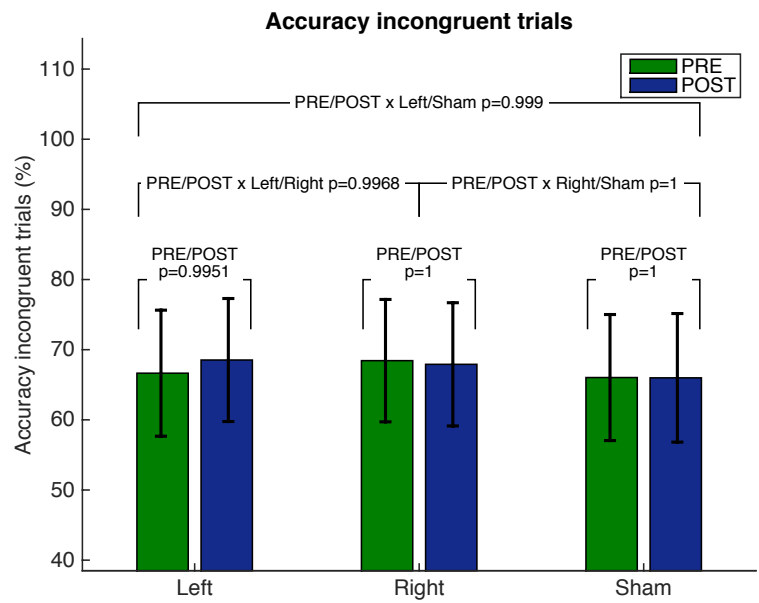

c)

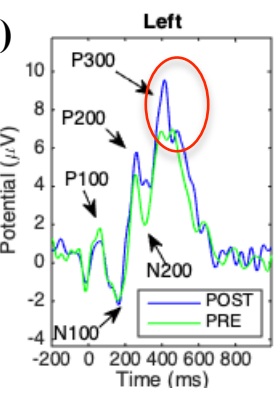

d)
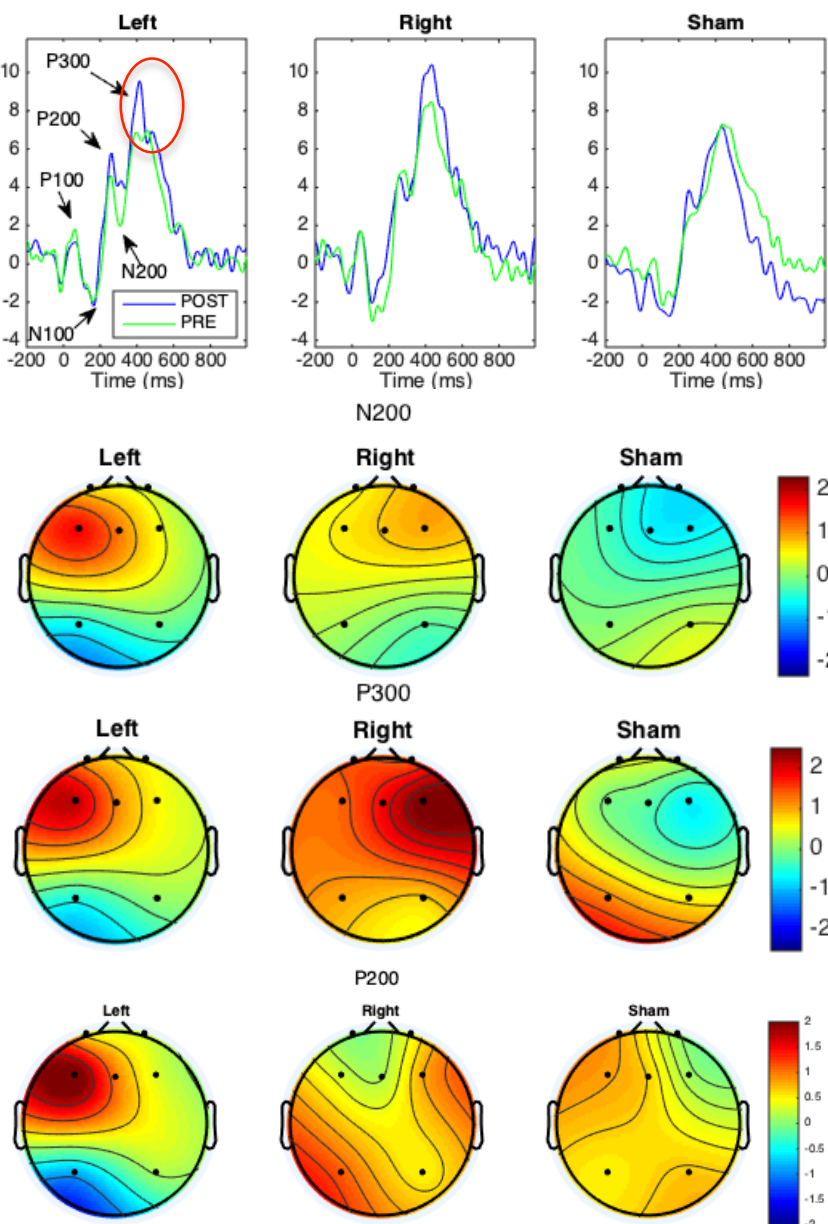

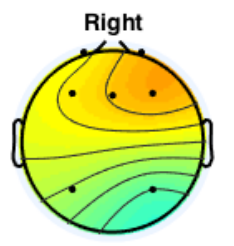

P300

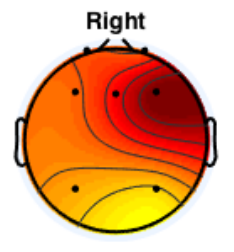

P200
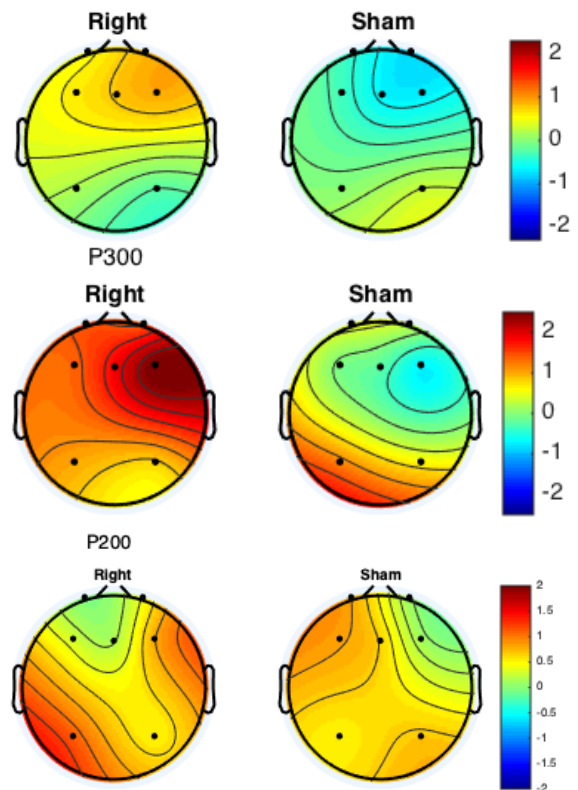

Figure 3. Flanker results. a) Mean reaction time and b) accuracy for incongruent trials and p values with 'mvt' correction. Error bars indicate confidence intervals. Significance indicated as $(*)=p<0.05,(* *)=p<0.01,(* * *)=p<0.001$. c) Grand average ERPs time-locked to incongruent stimuli. Waveforms correspond to the average of F3, Fz and F4 positions. The red circle indicates the significant amplitude changes compared to Sham. See Figure S2 in Supplement 2 for ERPs at individual electrodes. d) Scalp topographies of POST-PRE difference of P200, N200 and P300 amplitude (uV). Averaging time window for $\mathrm{P} 300=[260,360] \mathrm{ms}$. Averaging time window for $\mathrm{N} 200=[180,230] \mathrm{ms}$. 
medRxiv preprint doi: https://doi.org/10.1101/2020.01.13.20017335; this version posted January 16, 2020. The copyright holder for this preprint (which was not certified by peer review) is the author/funder, who has granted medRxiv a license to display the preprint in perpetuity.

All rights reserved. No reuse allowed without permission.

a)

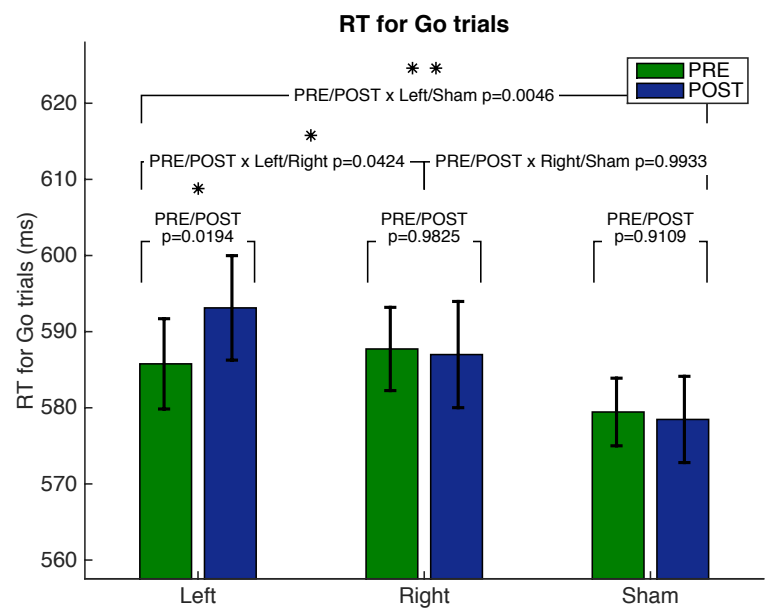

c)
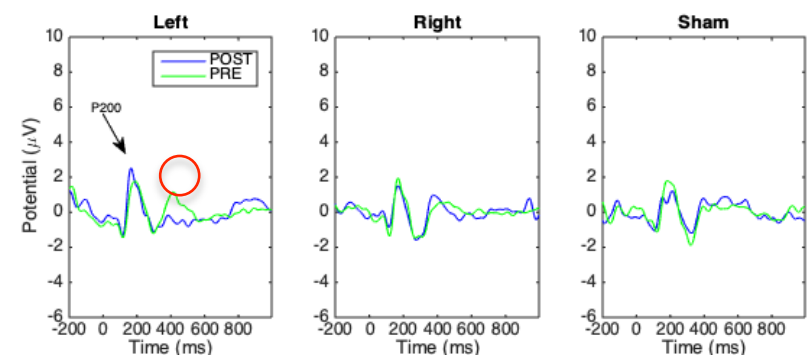

b)

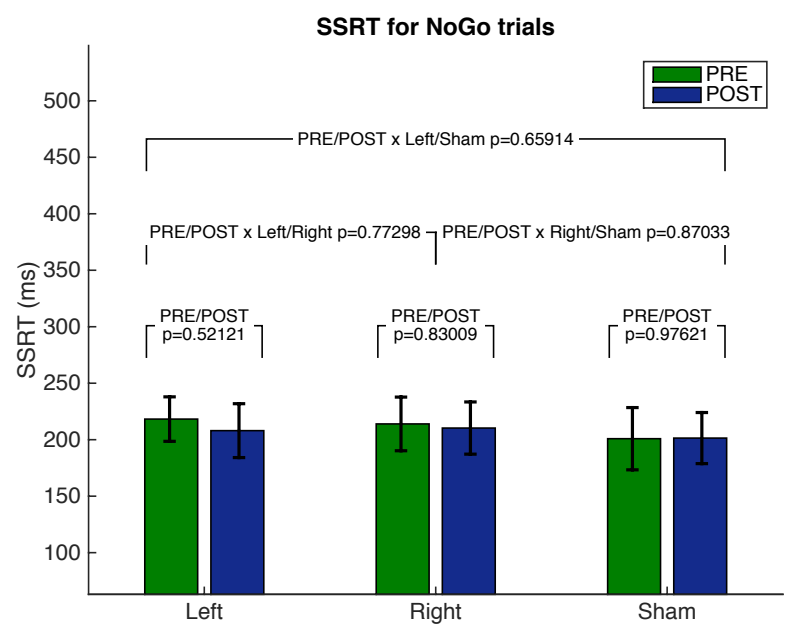

d)
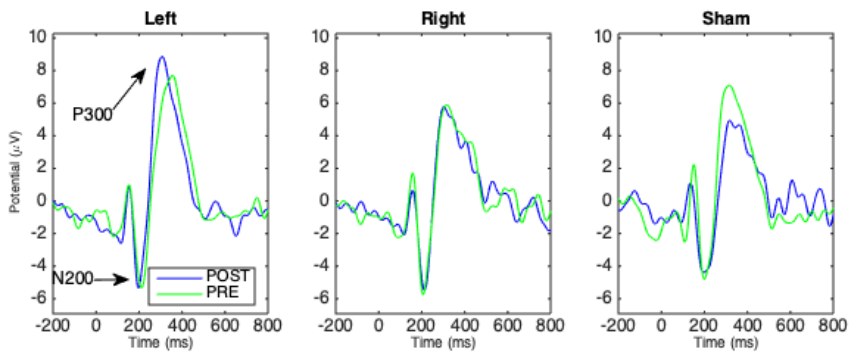

Figure 4. SST results. a) Mean reaction time for Go-trials. b) SSRT for Stop-trials. Error bars indicate confidence intervals. Significance indicated as $(*)=p<0.05,(* *)=p<0.01$. c) Grand average ERPs time-locked to Go-trials. The red circle indicates the significant amplitude changes compared to Sham. d) Grand average ERPs time-locked to Stop-trials. Waveforms correspond to the average of F3, Fz and F4 positions. 
medRxiv preprint doi: https://doi.org/10.1101/2020.01.13.20017335; this version posted January 16, 2020. The copyright holder for this preprint (which was not certified by peer review) is the author/funder, who has granted medRxiv a license to display the preprint in perpetuity.

All rights reserved. No reuse allowed without permission.
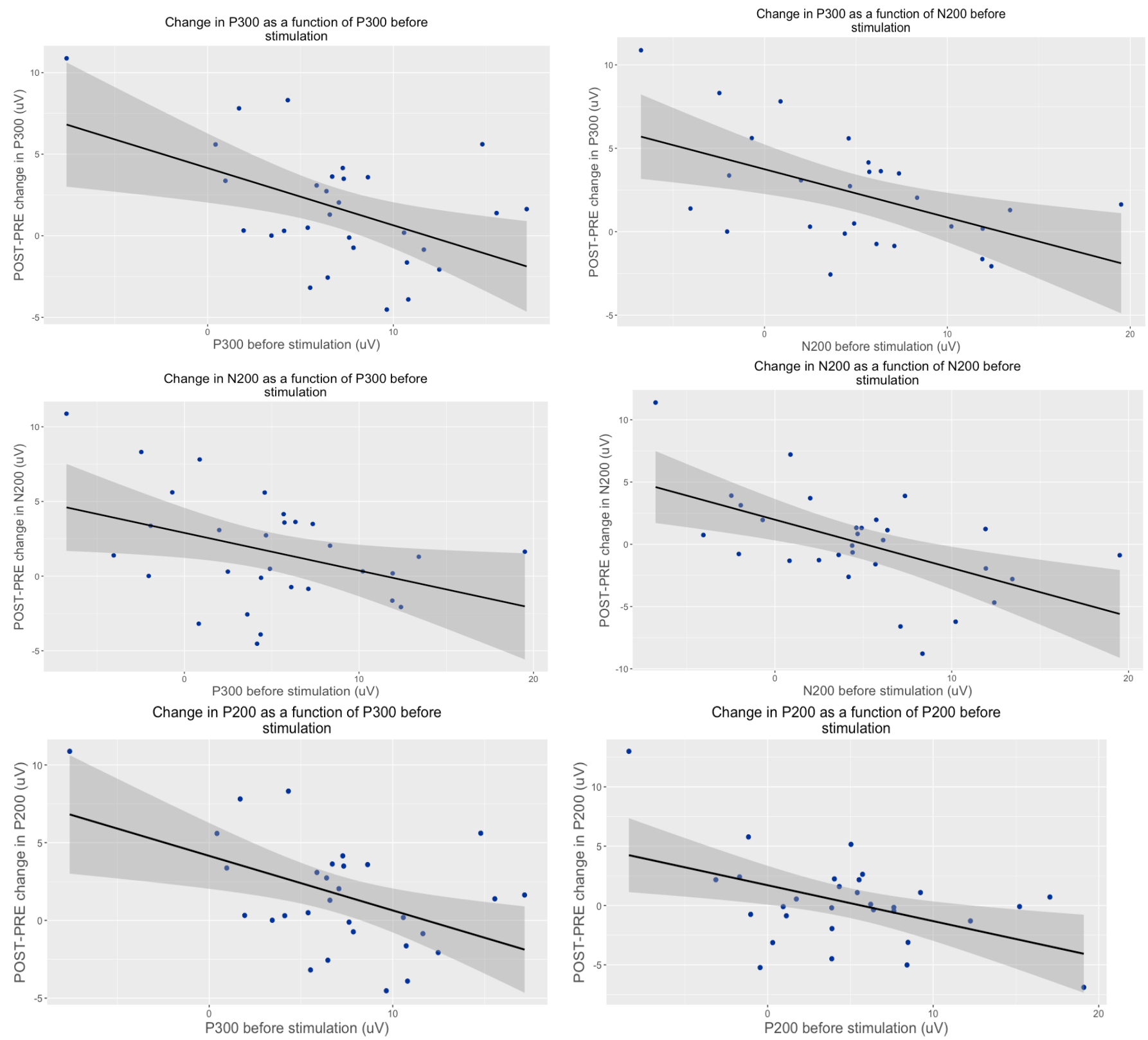

Figure 5. Scatter plots, regression lines and confidence intervals for significant state dependencies in the EFT. Top row: change in P300 as a function of P300 (left) and P200 (right) at baseline in the EFT. Second row: change in N200 amplitude as a function of P300 (left) and N200 (right) amplitude at baseline in the EFT. Third row: change in P200 amplitude as a function of P300 (left) and P200 (right) amplitude at baseline in the EFT. 